\title{
Liposclerosing myxofibrous tumour
}

\author{
Satvik N Pai @ , Mohan M Kumar
}

Orthopaedic Surgery, Sri Ramachandra Institute of Higher Education and Research, Chennai, Tamil Nadu, India

\section{Correspondence to Dr Satvik N Pai;} satvik.pai@gmail.com

Accepted 23 July 2021
D) Check for updates

(c) BMJ Publishing Group Limited 2021. No commercial re-use. See rights and permissions. Published by BMJ.

To cite: Pai SN,

Kumar MM. BMJ Case

Rep 2021;14:e245487

doi:10.1136/bcr-2021-

245487

\section{DESCRIPTION}

A 63-year-old man who was known to have chronic liver disease underwent a CT of the abdomen for evaluation of liver morphology. In the CT abdomen, he was coincidentally found to have an osteolytic lesion of the left proximal femur. He did not have any problems involving his left hip or thigh. On examination, no significant abnormalities could be detected clinically. Radiograph of the hip (figure 1) showed a solitary osteolytic lesion in the proximal femur involving the neck, intertrochanteric and subtrochanteric regions. The lesion had well-defined sclerotic margins, a narrow zone of transition and multiple septations within the matrix of the lesion. No cortical breach or periosteal reaction were present. MRI (figure 2) showed T2 and short tau inversion recovery hyperintense, T1 predominantly hypointense non-expansile intramedullary lesion with hypointense sclerotic rim. Thin septations, few hypointense foci and peripheral areas of fat were seen within the lesion. The patient was diagnosed to have liposclerosing myxofibrous tumour of the proximal femur. Owing to the predominantly benign nature of the condition and the absence of symptoms, the patient was managed conservatively. The patient was followed up for 6 months, was found to remain asymptomatic and the size of the lesion was found to remain constant.

Liposclerosing myxofibrous tumour is a rare tumour of the bone, which was first described in $1986 .{ }^{1}$ It is a benign fibro-osseous lesion, which has myxoid areas, osteoclastic activity, bone trabeculae similar to fibrous dysplasia, fat necrosis, ischaemic ossification and rarely cartilage components. ${ }^{2}$ It is found to occur most commonly in the fourth decade of life and proximal femur has been reported as the most common location. ${ }^{3}$ A few cases of malignant transformation of the lesion have been documented, and hence, it warrants close observation and follow-up. ${ }^{4}$

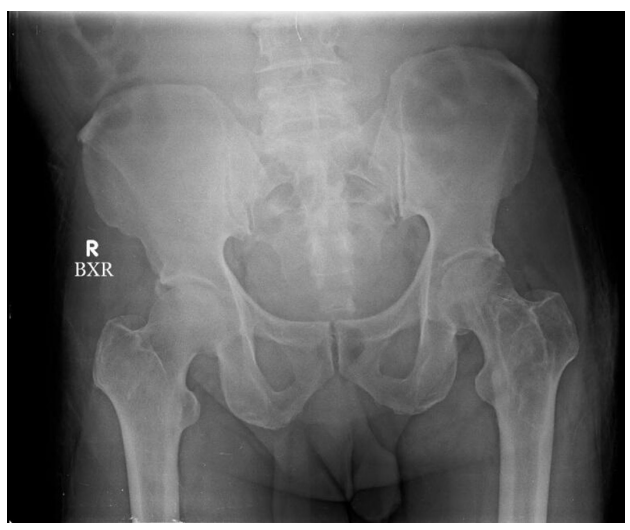

Figure 1 Radiograph of the pelvis showing a solitary lesion in the left proximal femur with a well-defined sclerotic rim. Septations are noted within the lesion.

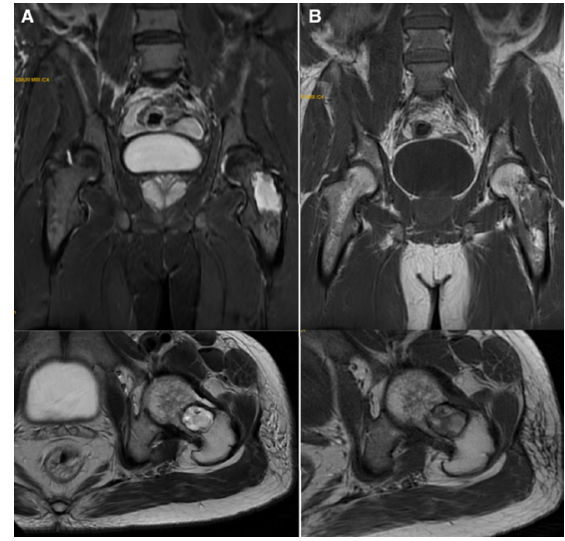

Figure 2 MRI showing a lesion in proximal femur which is hyperintense in (A) T2-weighted sequence and hypointense lesion in (B) T1-weighted sequence. No extraosseous extension is noted.

\section{Learning points}

- Liposclerosing myxofibrous tumour is a rare, benign fibro-osseous tumour of bone occurring most commonly in the proximal femur.

- It should be a differential when encountering a $\mathrm{T} 2$ hyperintense and $\mathrm{T} 1$ hypointense lesion with sclerotic rim.

- It can rarely transform into malignancy, and hence requires close observation and follow-up.

Contributors SNP collected all the data and digital images of the investigations of the patient, was responsible for the writing of the article. MMK was the chief operating surgeon under whom the patient was evaluated, and guided the entire process of preparation of the article, including reviewing the article.

Funding The authors have not declared a specific grant for this research from any funding agency in the public, commercial or not-for-profit sectors.

Competing interests None declared.

Patient consent for publication Obtained.

Provenance and peer review Not commissioned; externally peer-reviewed.

\section{ORCID iD}

Satvik N Pai http://orcid.org/0000-0002-3621-150X

\section{REFERENCES}

1 Técualt-Gómez R, Atencio-Chan A, Cario-Méndez AG, et al. [Bone liposclerosing myxofibrous tumor. Case presentation and literature review]. Acta Ortop Mex 2015;29:191-5.

2 Beytemür 0, Tetikkurt Ümit Seza, Albay C, et al. Liposclerosing myxofibrous tumor: a rare tumor of proximal femur. Eklem Hastalik Cerrahisi 2017;28:210-3.

3 Deel C, Hassell L. Liposclerosing Myxofibrous tumor: a review. Arch Pathol Lab Med 2016;140:473-6.

4 Campbell K, Wodajo F. Case report: two-step malignant transformation of a liposclerosing myxofibrous tumor of bone. Clin Orthop Relat Res 2008;466:2873-7. 
Images in...

Copyright 2021 BMJ Publishing Group. All rights reserved. For permission to reuse any of this content visit https://www.bmj.com/company/products-services/rights-and-licensing/permissions/

BMJ Case Report Fellows may re-use this article for personal use and teaching without any further permission.

Become a Fellow of BMJ Case Reports today and you can:

- Submit as many cases as you like

- Enjoy fast sympathetic peer review and rapid publication of accepted articles

Access all the published articles

Re-use any of the published material for personal use and teaching without further permission

Customer Service

If you have any further queries about your subscription, please contact our customer services team on +44 (0) 2071111105 or via email at support@bmj.com.

Visit casereports.bmj.com for more articles like this and to become a Fellow 